\title{
Effects of green synthesised silver nanoparticles (ST06-AgNPs) using curcumin derivative (ST06) on human cervical cancer cells (HeLa) in vitro and EAC tumor bearing mice models [Corrigendum]
}

\author{
Murugesan K, Koroth J, Srinivasan PP, et al. Int $J$ \\ Nanomedicine. 2019;14:5257-5270.
}

Following a review of our post-publication, we found the presentation of affiliations 2 and 4 are incorrect. They are currently listed as: ${ }^{2}$ Department of Pharmaceutical Chemistry, Manipal Academy of Higher Education, Manipal 576104,
Karnataka, India; ${ }^{4} \mathrm{KLE}$ Academy of Higher Education \& Research, KLE College of Pharmacy, Bangalore, KN, India. The correct presentation is: ${ }^{2}$ Manipal Academy of Higher Education, Manipal 576104, Karnataka, India; ${ }^{4}$ Department of Pharmaceutical Chemistry, KLE Academy of Higher Education \& Research, KLE College of Pharmacy, Bangalore, KN, India. The authors apologize for this error.

\section{Publish your work in this journal}

The International Journal of Nanomedicine is an international, peerreviewed journal focusing on the application of nanotechnology in diagnostics, therapeutics, and drug delivery systems throughout the biomedical field. This journal is indexed on PubMed Central, MedLine, CAS, SciSearch ${ }^{\mathbb{B}}$, Current Contents ${ }^{\mathbb{B}} /$ Clinical Medicine,
Journal Citation Reports/Science Edition, EMBase, Scopus and the Elsevier Bibliographic databases. The manuscript management system is completely online and includes a very quick and fair peer-review system, which is all easy to use. Visit http://www.dovepress.com/ testimonials.php to read real quotes from published authors. 